\title{
Development of an efficient endothelial cell specific vector using promoter and 5 ' untranslated sequences from the human preproendothelin-1 gene
}

\author{
JungYoon Cho ${ }^{1}$, WonChung Lim ${ }^{1}$ \\ Siyoul Jang ${ }^{2}$ and YoungJoo Lee Le $^{1,3}$ \\ ${ }^{1}$ Department of Bioscience and Biotechnology \\ College of Engineering \\ Sejong University, Seoul 143-747, Korea \\ ${ }^{2}$ College of Engineering \\ Kookmin University, Seoul, Korea \\ ${ }^{3}$ Corresponding Author: Tel, 82-2-3408-3766; \\ Fax, 82-2-3408-3334; E-mail, vjlee@sejong.ac.kr
}

Accepted 3 June 2003

Abbreviations: BAEC, bovine aortic endothelial cells; CPAE, calf pulmonary artery endothelial cells; HUVEC, human umbilical vein endothelial cells; ppET-1, preproendothelin-1

\begin{abstract}
We report here, that a vector constructed based on ppET-1 gene promoter and $5^{\prime}$ untranslated region induced a high level of gene expression in endothelial cells and the specificity is even further enhanced under hypoxia-mimic conditions due to a natural hypoxia responsive element within the promoter region. A naked DNA vector that confers endothelial cell specific gene expression as well as efficient levels of gene expression was constructed with an endothelial cell specific naked DNA vector, pETlong, by using the full length promoter of the preproendothelin-1 gene and the entire $5^{\prime}$ untranslated region upstream from the start codon. Inclusion of the entire 5 ' untranslated region in $p E T$ Tlong increased gene expression 2.96 fold as compared with that from pETshort, which contains only the promoter sequences. Reporter gene expression from pETlong was 7.9 fold higher as compared with that from CMV-driven promoter based vector in calf pulmonary endothelial cells. However, in nonendothelial COS cells, luciferase activity from pETlong was only 0.3 fold as compared with that of CMV-based vector. Similar results were observed in other nonendothelial cells. These results demonstrate that the pETlong drives gene expression in endothelial cells with high efficacy and specificity. We have examined hypo-
\end{abstract}

xia responsiveness of $p E$ Tlong as the promoter region of the preproendothelin-1 gene contains hypoxia responsive elements. The activity of the pETlong vector was increased 1.6 fold under hypoxia-mimic conditions using cobalt chloride. The high levels of hypoxia-inducible expression in endothelial cells relative to the low levels of background expression in other cells shows that $p$ ETlong could be a useful tool for vascular targeting of vascular disease and cancer gene therapy.

Keywords: endothelial cell specific vector; gene therapy; naked DNA, preproendothelin-1; 5' untranslated region

\section{Introduction}

The success of gene therapy depends largely on the efficacy of gene delivery vector systems that can selectively and efficiently deliver genes to target organs with minimal toxicity (Niidome and Huang, 2002). Development of efficient endothelial cell selective vector systems will be invaluable to cancer gene therapy as well as other vascular diseases (Martin and Murray, 2000). Most frequently used strategies to develop such vectors are either using tissue targeting vector systems or tissue specific promoters (Varda-Bloom et al., 2001). A few studies have reported construction of endothelial cell specific viral vectors using sequences from von-Willebrand factor, intracellular adhesion molecule 2, vascular endothelial growth factor receptor, or E-selectin (Modlich et al., 2000; He et al., 2001). However, one of the most frequently encountered problems with such tissue specific vectors using endogenous cell specific promoters is low levels of gene expression compared with widespread nonspecific viral promoters even when tissue specificity is achieved (Modlich et al., 2000; Shibata et al., 2000). In some cases, exogenous cytokineinducible elements were inserted to $5^{\prime}$ upstream of the promoters to overcome this low gene expression activity (Modlich et al., 2000).

To develop highly efficient and endothelial cell specific expression plasmids, we chose to use the preproendothelin-1 (ppET-1) gene promoter because it's regulation and expression in endothelial cells are well studied (Wilson et al., 1990; Bu and Quertermous, 1997; 
Minchenko and Caro, 2000). A high specific vasoconstrictor, ppET-1, is produced by vascular endothelium in response to various signals such as injury, hypoxia, ischemia, and inflammatory mediators (Aversa et al., 1997). Hypoxic responsiveness of ppET-1 is mediated through an inverted hypoxia responsive elements is located at -118 upstream of the transcription start site of the ppET-1 gene (Yamashita et al., 2001). In our vector design, we have used not only the full length promoter sequences of $p p E T-1$ gene but also the entire 5 ' untranslated region upstream from the start codon of the ppET-1 gene to improve the efficacy of ppET-1 gene promoter activity. Inclusion of intronic sequences to expression plasmid has been reported to enhance gene expression both in vitro and in vivo. Simari et al. showed that addition of $5^{\prime}$ intronic sequences to cytomegalovirus immediate early promoter resulted in about 6 fold increase in gene expression (Simari et al., 1998). Kay's group constructed a vector with hepatic factor IX intronic sequences expressing enhanced levels of proteins (Miao et al., 2000). In this report, we show that our newly constructed vector based on ppET-1 gene promoter and $5^{\prime}$ untranslated region drives high level of gene expression in endothelial cells and the specificity is even further enhanced under hypoxiamimic conditions due to a natural hypoxia responsive element within the promoter region. Our results show that the vector could be a potentially useful tool for vascular targeting of vascular disease and cancer gene therapy.

\section{Materials and Methods}

\section{Cell culture}

BAEC (Bovine aortic endothelial cells), originally obtained from a local slaughterhouse were gifts from $\mathrm{Dr}$. Inho Jo (Kim et al., 1999). BAEC and COS cells were maintained in DMEM containing $1 \times$ antibiotic/antimycotic mix, 5 mM N-(2-hydroxyethyl)-piperazine- $\mathrm{N}-2$ ethanesulfonic acid, and $0.37 \%$ sodium bicarbonate, supplemented with $10 \%$ fetal bovine serum (FBS). CPAE (Calf pulmonary artery endothelial cells) were purchased from the Korea Cell Line Bank and grown in RPMI with 20\% FBS. HUVEC (Human umbilical vein endothelial cells) purchased from BioWhittaker, Inc (Walkersville, MD) were grown in endothelial cell growth medium kit 2 containing 2\% FBS (Bio Whittaker, Inc.). All the cell lines were grown at $37^{\circ} \mathrm{C}$ in humidified $95 \%$ air $/ 5 \% \quad \mathrm{CO}_{2}$ and fed every $1-2$ days. For hypoxia-mimic condition, cobalt chloride was added to cell cultures to a final concentration of 100 $\mu \mathrm{M}$ for $24 \mathrm{~h}$.

\section{Plasmid construction}

The full length ppET-1 gene promoter and its entire 5' untranslated region was cloned by PCR amplification of human genomic DNA, using a pair of primers, 5'-ACGCGTTCTGAAGTTAGCAGTGAT 3 ' and 5'-AAGCTTCCGTTCGCCTGGCGCA 3' for pETshort and 5'-ACGCGTTCTGAAGTTAGCAGTGAT 3' and 5'AAGCTTTCTGAAAAAAAGGATCA $3^{\prime}$ for pETlong. These primers contain the Mlul linker at the $5^{\prime}$ end and the HindIII linker at the $3^{\prime}$ end. The amplified cDNA was replaced with the promoter region of pcDNA3-Luc using Mlul/HindIII site thereby making the backbone identical to pcDNA3 vector (Invitrogen Inc., Carlsbad, CA). pETshort plasmid contains 210 bp of ppET-1 gene promoter region. pETlong contains $210 \mathrm{bp}$ of promoter sequences and its entire $5^{\prime}$ untranslated region consisiting of 267 bp of exon 1 . The start codon of the inserted gene was designed to coincide with the original ppET-1 gene.

\section{Transient transfection}

BAEC, CPAE, HUVEC, and COS cells were transfected by the calcium phosphate-DNA coprecipitation method. A total of $0.5 \mu \mathrm{g}$ of DNA in $25 \mu \mathrm{l}$ of $\mathrm{CaCl}_{2}$. $\mathrm{H}_{2} \mathrm{O}(250 \mathrm{mM} \mathrm{CaCl}$ ) was mixed with $25 \mu \mathrm{l}$ of $2 x$ HBS $\left(280 \mathrm{mM} \mathrm{NaCl}, 10 \mathrm{mM} \mathrm{KCl}, 1.5 \mathrm{mM} \mathrm{Na}_{2} \mathrm{HPO}_{4}\right.$. $2 \mathrm{H}_{2} \mathrm{O}, 12 \mathrm{mM}$ dextrose, $50 \mathrm{mM}$ HEPES) with constant bubbling and within 5 to $10 \mathrm{~min}$ this solution was added to each well. HUVEC were transfected at $90 \%$ confluence; other cell lines were transfected at $70 \%$ confluence.

\section{Luciferase assay}

The cells were incubated in 24-well plates for about $24 \mathrm{~h}$ after transient transfection. The next day, transfected cells were washed with PBS and lysed with the Reporter Lysis Buffer (Promega, Madison, WI). Luciferase expression was assayed using a luciferase assay kit (Promega, Madison, WI) according to the manufacturer's instructions. Luciferase activity was determined by using an Auto Lumat LB9507 luminometer and expressed as relative light units. Transfections were performed in triplicate more than three times. Data are expressed as the mean \pm SEM and shown for representative experiments.

\section{Results}

\section{Construction of ppET-1 based expression vector}

To develop endothelial cell specific expression plasmid for naked DNA gene therapy, we chose to use the promoter of human ppET-1 gene because its regulation and expression in endothelial cells are very 

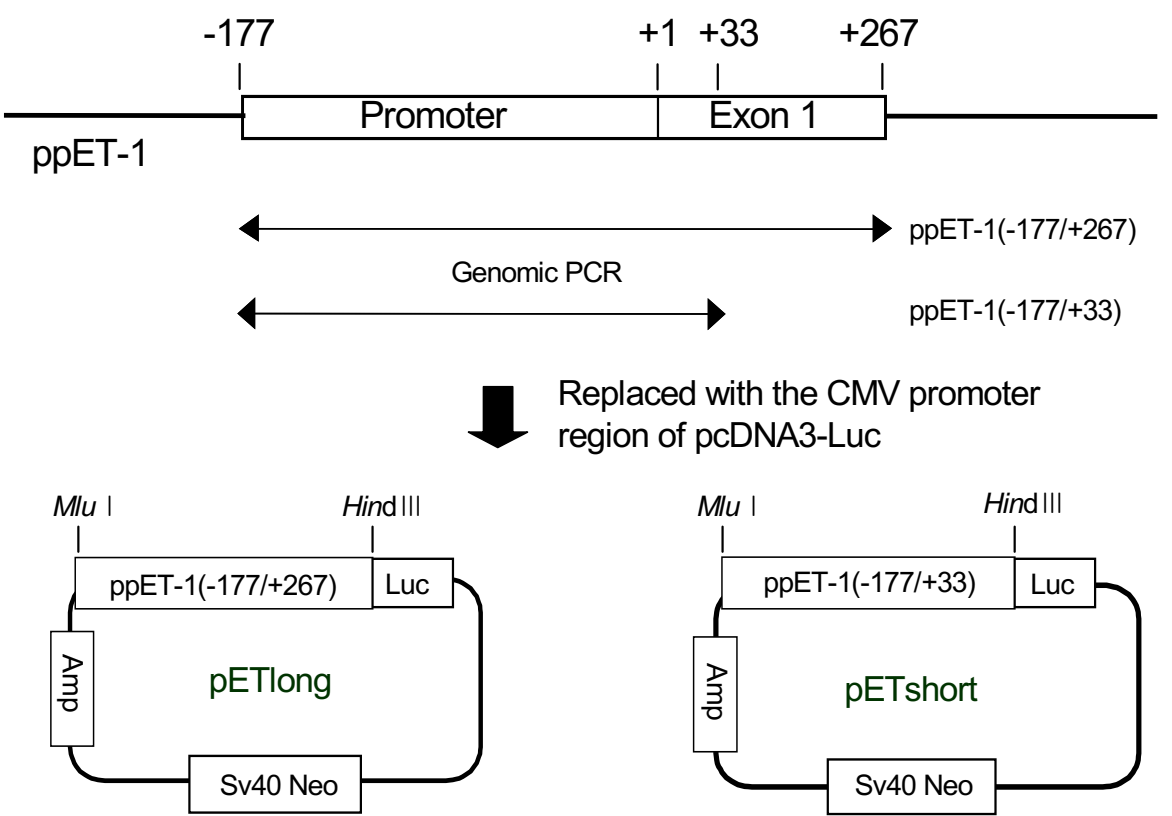

Figure 1. Structures of $p E T$ Tlong and $p E T$ short. $p E T$ Tong and $p E T$ short were constructed as described under Materials and methods.

well characterized. Previous studies have adopted the $-177 \mathrm{bp}$ to $+33 \mathrm{bp}$ (relative to transcriptional start site) region of the ppET-1 gene for construction of an endothelial cell specific retroviral gene therapy vector (Mavria et al., 2000). DNA fragments containing the same region $(-177$ to +33$)$ and a longer fragment down just upstream to the start codon $(-177$ to +267$)$ were amplified by PCR from human genomic DNA. Both the fragments were replaced by CMV promoter in pcDNA3-Luc to construct pETlong and pETshort (Figure 1). pETlong consists not only the promoter but also its entire $5^{\prime}$ untranslated region of ppET-1 gene. In most cases, 5' untranslated regions and introns have not been used in expression vectors because of their large sizes and absence of dramatic enhancer elements. However, several data demonstrate that $5^{\prime}$ untranslated regions, introns, or $3^{\prime}$ untranslated regions can contribute to increase in gene expression (Brinster et al., 1988; Palmiter et al., 1991; Liu et al., 1995).

\section{Effect of 5' untranslated sequences in pETlong}

First, we have examined the effect of the entire $5^{\prime}$ untranslated sequences of ppET-1 gene on gene expression level. We have compared pETlong with pETshort for their levels of luciferase gene expression by transient transfection in nonendothelial COS cells. Relative luciferase units from $p E T$ Tlong which includes 5 ' untranslated leader sequences was 46,522 $\pm 8,538$ which is 2.96 fold higher than pETshort $(15,720 \pm$ 1,389 ) in COS cells (Figure 2A). Similar results were obtained in BAEC (Figure 2B).

\section{Endothelial cell-specific expression of $p E T$ Tlong}

We next proceeded to investigate the expression profile in endothelial cells. Three different endothelial cells were transiently transfected with pETlong plasmids and levels of luciferase activity were measured $24 \mathrm{~h}$ after transfection. Gene expression levels were normalized by luciferase activity from parallel transfected control pcDNA3 plasmid for transfection efficiencies. We did not cotransfected control $\beta$-galactosidase plasmids that promoter interference might occur. Rather, we prepared, transfected same amounts of either pETlong or pcDNA3-Luc each in triplicate, and assayed four different cells simultaneously. Reporter gene expression from pETlong was $8( \pm 0.80)$ fold higher as compared with that from CMV-driven promoter based vector in CPAE. However, in nonendothelial COS cells, luciferase activity from $\mathrm{pETlong}$ was only $0.3( \pm 0.01)$ fold as compared with that of CMV-based vector. Expression patterns between endothelial cells were similar. HUVEC and BAEC expressed about 3 fold lower levels of luciferase compared with CPAE but still about 8 fold more than COS cells (Figure 3 ).

\section{Effect of hypoxia on pETlong}

Yamashita et al. have identified a HIF-1 binding site at -118 bp upstream of the transcription start site (Yamashita et al., 2001). We have examined whether expression from pETlong responds to hypoxia in CPAE. Cells were transiently transfected with pETlong and incubated with cobalt chloride $(100 \mu \mathrm{M})$ for 24 h. As shown in Figure 4, the relative luciferase units 
A

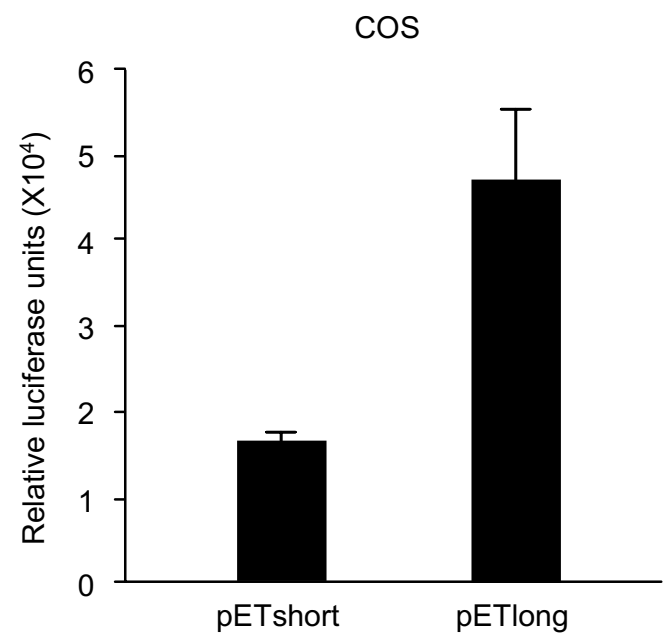

B

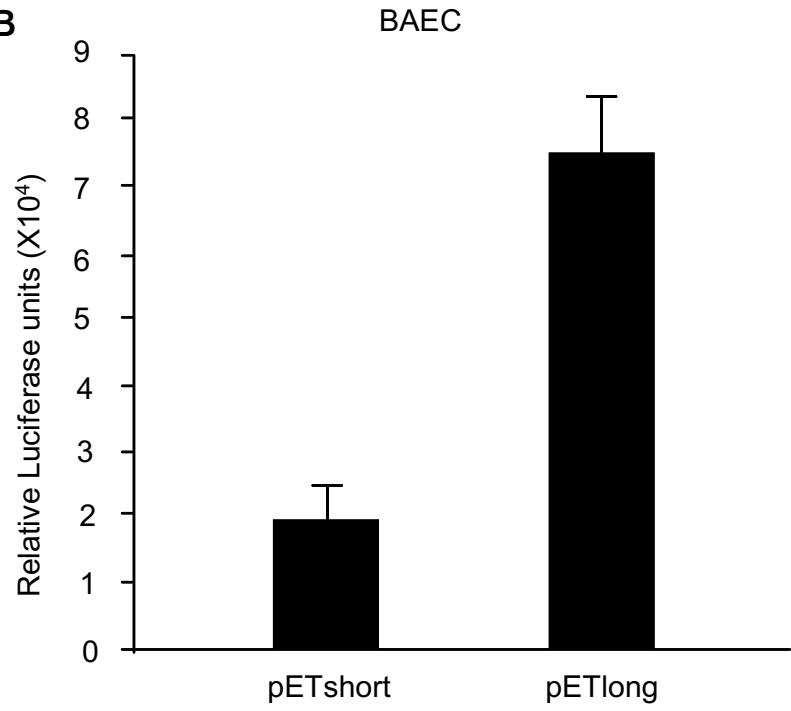

Figure 2. Comparison of levels of luciferase reporter gene expression between $p E T$ short and $p E T$ Tlong vectors. Constructs were transfected into COS cell (A) and BAEC (B) by calcium phosphate. An approximately 3 fold increase in luciferase production was observed in cells transfected $\mathrm{pET}$ Tlong when compared with $\mathrm{pETshort.} \mathrm{Transfections} \mathrm{were} \mathrm{performed} \mathrm{in} \mathrm{triplicate} \mathrm{more} \mathrm{than} \mathrm{three} \mathrm{times.} \mathrm{One} \mathrm{representative} \mathrm{result} \mathrm{is} \mathrm{shown}$ in this figure. Data are expressed as the mean \pm SEM.

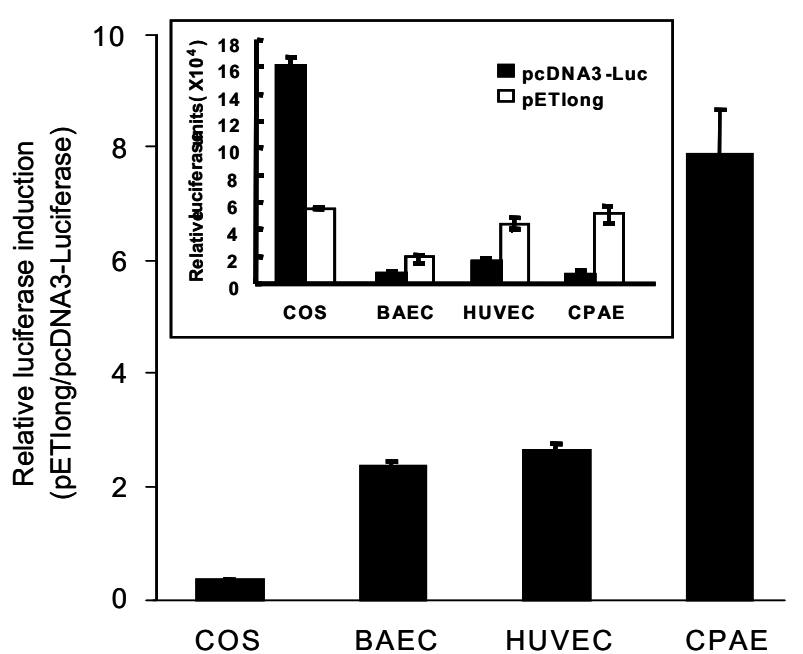

Figure 3. Endothelial cell specificity of the $\mathrm{pET}$ Tlong. A panel of endothelial (BAEC, CPAE, and HUVEC) and non-endothelial cell lines (COS) were transfected with PETlong and pcDNA3-Luciferase for determination of luciferase expression. Endotherial cells specificity of $p E T$ Tong was assessed by ratio of $p E T$ Tlong expression level/pcDNA3LUC expression level. The inset shows the raw luciferase data from one experiment. Transfections were performed in triplicate more than three times. One presentative result is shown in this figure. Data are expressed as the mean $\pm S E M$.

of pETlong under hypoxia-mimic conditions was $199,000 \pm 370$ which is 1.6 fold higher compared with normoxia $(124,000 \pm 524)$ in CPAE. These data suggested that expression from $\mathrm{pETlong}$ is inducible in hypoxia.

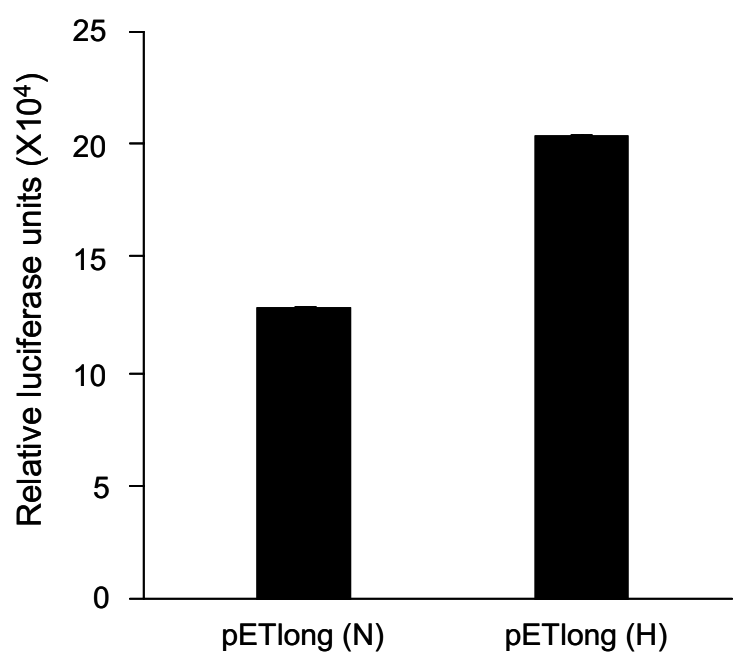

Figure 4. Effect of hypoxia on luciferase activity in CPAE expressing $\mathrm{pET}$ Tlong vector. Compared to normoxic control $(\mathrm{N})$, there is a 1.6 fold increase in luciferase production from cells exposed under hypoxiamimic conditions $(H)$ for $24 \mathrm{~h}$. Transfections were performed in triplicate more than two times. One presentative result is shown in this figure. Data are expressed as the mean $\pm S E M$.

\section{Discussion}

The major obstacle for a success of gene therapy is the lack of efficient gene delivery vehicles (Verma and Somia, 1997). Nonviral vectors based on simple plasmid DNA are considered to be safe, simple, and easier to use. However, in most cases the duration 
of expression is shorter compared with viral vectors. Long-term persistent gene expression was often considered to be the major advantage of using viral integrating vectors. However, recent studies showed that gene expression could persist more than a year even with the episomal plasmid vectors with tissue specific promoters (Chen et al., 2001; Miao et al., 2001). Nonviral vectors containing a modified endogenous alpha- 1 antitrypsin promoter region produced not only tissue specific expression but also elevated, sustained level of gene expression for at least 1.5 years (Miao et al., 2001). For both viral and nonviral vectors, localized, tissue specific expression is desirable that it would dramatically reduce its side effects by localizing the expression of the therapeutic genes. Production of sustained gene expression by tissue specific nonviral vector systems is probably by the reduction of an immune response to the transgene (Niidome and Huang, 2002). Therefore, development of tissue specific expression nonviral vectors is important for protection of healthy unaffected organs and for duration of gene expression as well.

The lumen of all blood vessels and heart is covered by endothelial cells (Schlaeger et al., 1995). These cells are often targets for gene therapy because they are very closely involved in pathological status such as angiogenesis, atherosclerosis, tumor growth, myocardial infarction, and limb ischemia. Several reports have shown development of endothelial cell specific vector systems, each aiming ultimately for safe and efficient expression vector for human application. Ma et al. have delivered oligonucleotides using special formulation of lipids (Ma et al., 2002). $\mathrm{He}$ et al. have examined FLk-1 and thrombomodulin promoters in endothelial cells of transgenic pigs that vascular endothelium is the most immediate barrier between the xenogeneic donor organ and host immune systems (He et al., 2001). Modlich et al. have developed endothelial cell specific promoter based retroviral vectors by the use of hypoxic and cytokineinducible enhancers (Modlich et al., 2000). Here in this study, we demonstrate that our newly developed vector pETlong efficiently expressed the exogenously added gene in endothelial cells in in vitro. pETlong was constructed to contain not only the full length promoter of ppET-1 gene but also its entire 5' untranslated region. In addition, our vector was designed in such a way that the start codon of the original ppET-1 gene. Expression from pETlong were approximately 8 fold higher than those from commercially available pcDNA3 in CPAE cells. In addition, luciferase activity from $p E$ Tlong was approximately 3 fold higher compared with $\mathrm{pETshort,} \mathrm{which} \mathrm{harbors} \mathrm{same} \mathrm{promoter}$ regions of a retroviral vector reported by Mavria et al. (2000) in COS cells. This strategy is based on a variety of data that high levels of gene expression are determined not only by the promoter but also by the untranslated leader sequences of the coding region (Lee et al., 2000; Jin et al., 2002). Expression from $p E T$ Tlong was far greater than that from CMVbased vector in endothelial cells and was further enhanced under hypoxia-mimic conditions. pETlong would not only be useful for gene therapy but also would be invaluable for various gene transfer studies targeting endothelial cells.

\section{Acknowledgement}

This work was funded by the Korean National Institute of Toxicological Research, the Korean Ministry of Health and Welfare (01-PJ1-Pg1-01CH06-0003) and BK 21 program to YJL.

\section{References}

Aversa CR, Oparil S, Caro J, Li H, Sun SD, Chen YF, Swerdel MR, Monticello TM, Durham SK, Minchenko A, Lira SA, Webb ML. Hypoxia stimulates human preproendothelin-1 promoter activity in transgenic mice. Am J Physiol 1997;273: L848-55

Brinster RL, Allen JM, Behringer RR, Gelinas RE, Palmiter $\mathrm{RD}$. Introns increase transcriptional efficiency in transgenic mice. Proc Natl Acad Sci USA 1988;85:836-40

$\mathrm{Bu}$ X, Quertermous T. Identification of an Endothelial Cellspecific Regulatory Region in the Murine Endothelin-1 Gene. J Biol Chem 1997;272:32613-22

Chen ZY, Yant SR, He CY, Meuse L, Shen S, Kay MA. Linear DNAs concatemerize in vivo and result in sustained transgene expression in mouse liver. Mol Ther 2001;3:403-10

$\mathrm{He} Z$, She R, Sumitran-Holgersson S, Blomberg P, Islam KB, Holgersson J. The in vitro activity and specificity of human endothelial cell-specific promoters in porcine cells. Xenotransplantation 2001;8:202-12

Jeong JO, Byun JH, Jeon ES, Gwon HC, Lim YS, Park JW, Yeo SJ, Lee YJ, Kim SY, Kim DK. Improved expression by cytomegalovirus promoter/enhancer and behavior of vascular endothelial growth factor gene after myocardial injection of naked DNA. Exp Mol Med 2002;34:278-84

Kim HP, Lee JY, Jeong JK, Bae SW, Lee HK, Jo I. Nongenomic stimulation of nitric oxide release by estrogen is mediated by estrogen receptor alpha localized in caveolae. Biochem Biophys Res Commun 1999;263:257-62

Lee YJ, Park EJ, Yu SS, Kim DK, Kim S. Improved expression of vascular endothelial growth factor by naked DNA in mouse skeletal muscles: implication for gene therapy of ischemic diseases. Biochem Biophys Res Commun 2000; 272:230-5

Liu K, Sandgren EP, Palmiter RD, Stein A. Rat growth hormone gene introns stimulate nucleosome alignment in vitro and in transgenic mice. Proc Natl Acad Sci USA 1995;92:7724-8

Ma Z, Zhang J, Alber S, Dileo J, Negishi Y, Stolz D, Watkins 
S, Huang L, Pitt B, Li S. Lipid-mediated delivery of oligonucleotide to pulmonary endothelium. Am J Respir Cell Mol Biol 2002;27:151-9

Martin S, Murray J. Gene-transfer systems for human endothelial cells. Adv Drug Deliv Rev 2000;41:223-33

Mavria G, Jager U, Porter CD. Generation of a high titre retroviral vector for endothelial cell-specific gene expression in vivo. Gene Ther 2000;7:368-76

Miao $\mathrm{CH}$, Ohashi K, Patijn GA, Meuse L, Ye X, Thompson $A R$, Kay MA. Inclusion of the hepatic locus control region, an intron, and untranslated region increases and stabilizes hepatic factor IX gene expression in vivo but not in vitro. Mol Ther 2000;1:522-32

Miao CH, Thompson AR, Loeb K, Ye X. Long-term and therapeutic-level hepatic gene expression of human factor IX after naked plasmid transfer in vivo. Mol Ther 2001;3:947-57

Minchenko A, Caro J. Regulation of endothelin-1 gene expression in human microvascular endothelial cells by hypoxia and cobalt: role of hypoxia responsive element. Mol Cell Biochem 2000;208:53-62

Modlich U, Pugh CW, Bicknell R. Increasing endothelial cell specific expression by the use of heterologous hypoxic and cytokine-inducible enhancers. Gene Ther 2000;7:896-902

Niidome T, Huang L. Gene Therapy Progress and Prospects: Nonviral vectors. Gene Ther 2002;9:1647-52

Palmiter RD, Sandgren EP, Avarbock MR, Allen DD, Brinster $\mathrm{RL}$. Heterologous introns can enhance expression of transgenes in mice. Proc Natl Acad Sci USA 1991;88:478-82
Schlaeger TM, Qin Y, Fujiwara Y, Magram J, Sato TN. Vascular endothelial cell lineage-specific promoter in transgenic mice. Development 1995;121:1089-98

Shibata T, Giaccia AJ, Brown JM. Development of a hypoxiaresponsive vector for tumor-specific gene therapy. Gene Ther 2000;7:493-8

Simari RD, Yang ZY, Ling X, Stephan D, Perkins ND, Nabel GJ, Nabel EG. Requirements for enhanced transgene expression by untranslated sequences from the human cytomegalovirus immediate-early gene. Mol Med 1998;4:700-6

Varda-Bloom N, Shaish A, Gonen A, Levanon K, Greenbereger S, Ferber S, Levkovitz H, Castel D, Goldberg I, Afek A, Kopolovitc $Y$, Harats D. Tissue-specific gene therapy directed to tumor angiogenesis. Gene Ther 2001;8:819-27

Verma IM, Somia N. Gene therapy - promises, problems and prospects. Nature 1997;389:239-42

Wilson DB, Dorfman DM, Orkin SH. A nonerythroid GATAbinding protein is required for function of the human preproendothelin-1 promoter in endothelial cells. Mol Cell Biol 1990; 10:4854-62

Yamashita K, Discher DJ, Hu J, Bishopric NH, Webster KA. Molecular regulation of the endothelin-1 gene by hypoxia. Contributions of hypoxia-inducible factor-1, activator protein-1, GATA-2, AND p300/CBP. J Biol Chem 2001;276:1264553 